\title{
Application Research of Micro-course in Vocational Education
}

\author{
M.Q.Wang \& W.Tian \\ Institute of Engineering Technology China, Changchun
}

Q.Q.Yin

International exchange college, Chang Chun Vocational Institute of Technology

\begin{abstract}
In this article, through analyzing the current situation of vocational education, combining the resources of the network's role in the vocational education, puts forward the course in the application of the necessity and importance of vocational education. With traditional network teaching resources, such as online courses such as contrast, analysis sums up the characteristics and superiority of micro course, for the production of micro course put forward some effective Suggestions.
\end{abstract}

KEYWORD: Micro-course; reform of teaching

A significant characteristic exists in vocational education is different levels of students' knowledge and skills constitute. So that layered teaching methods is difficult to implement. At this stage, the main channel for students to learn is from classroom. The teaching model use more chapter-teaching and thematic-teaching, which have wide coverage in content. That easily lead to some students have insufficient learning in knowledge. Overseas students have less space of independent thinking, and unable to complete the knowledge reconstruct. Meanwhile, the tutoring courses teaching materials use more network model to present. Since the vast majority of online courses are organized in sections, so that students need to use a lot of extra time in study. Students' self-control is poor during study, and they have short attention span. For different learning needs, they cannot guarantee that there are more time to engage in extra-curricular learning. In addition, during a long time, the single learning mode in both inside and outside class, fuzzy directivity and pertinence of assisted learning curriculum are a direct result of students' inefficient learning. Therefore, we need an efficient and effective way to supply and improve teaching.

Driven by the rapid development of internet and multimedia technologies, "Micro-course" has changed the presentation and learning courses, and broaden teachers' educational ideas as a new teaching resource. It remodels the teacher-student relationship, truly realizes student-centered, and achieves learning autonomy. This is revolution of a "learning"-centered teaching value shock to "teaching"-centered teaching value. It have got recognition by many higher education institutions from different countries.

\section{CONNOTATION OF "MICRO-COURSE"}

During the development of domestic and international teaching reform, theory lags behind the practice is not uncommon. Currently, theorists' recognization of Micro-course is still in the "prescientific" stage. There is no generally accepted concept of the system. Here we can only say "Microcourse" is based mainly on instructional design ideas, according to the new curriculum standards and teaching practice requirements [1], which use video as the main supporter, recorded a knowledge of teachers around inside and outside the classroom during teaching process (key point, difficult point, doubtful point) or during teaching activities undertaken by the whole process of teaching and learning process. These knowledge points, which can be interpreted materials, intensive explanation of questions, summary of the test center; it can be a method to impart knowledge of teaching experience and other skills. It is for the purpose of learners have the best results during independent learning. Through informatization teaching design and rich media knowledge, to conduct a brief and complete teaching activities.

\section{SIGNIFICANCE OF MICRO-COURSE CONSTRUCTION}

\section{1 creating change of traditional education}

Although the advocation of giving priority to study has been a long time, but all the curriculum design, course content, classroom interaction often are based on what teachers think students will, by virtue of the experience of the past to design. In short, what will 
be granted and how long to grant are awarded by the teacher and master. Although we have focused in this model, but still fewer scruples on students' needs and feelings, students only can passively accept it.

Micro-course has basic features like break the constraints of time, get what they need, repeat, emphasize interactive learning experience. Its core is to emphasize "learning". Students' learning experience is static, that it emphasized the interpretation and communication of learning. Experience and interactive is a kind of learning method for combining static and dynamic, and its value orientation still emphasizes teaching students. These characteristics challenge the previous emphasis on "teaching" fundamentally mode, which is reflected in the learning-centered values. Thereby affirmed the students' learning autonomy, which by transfer "teaching" to "studying". That thanks to the basic characteristics of the Micro-course.

\subsection{Re-integration and distribution of educational resources}

Micro-course changed our traditional lecture-style teaching model, to give students more learning and thinking space. The length of course that five minutes, reducing the amount of redundant information. It is relatively easy to learn. Microcourse is not only different from simple multimedia teaching, but also different from the present teaching. It brings a completely different feeling to learn: it is to mobilize all the senses of people to participate in learning, vision, hearing, imagination, and has such characteristics like delicate, short, freedom, using and efficient[2].

Online course mainly based on video, like "picture + Sound" - students looking at the video screen with listening to the sound recording. That is very easy to fall asleep. While the micro-course is constituted by the "text + music + screen", it converts the voice to relaxing music. That creates a relaxed atmosphere, can make people calm down. Reading the concise text instead of listening to commentary is in favor of focus people's attention, whether collective or individual studying, you will see concentrate on learning.

In addition, micro-course can be completed by using common media technology, which can meet the teachers' and students' requirement for microexpansion, updating and uploading. Students are encouraged to participate in the creation, so that the dominant position of students will have good value reflects. That will stimulate students' enthusiasm for learning. This creation of micro-course guide students actively engage in deep thinking, that is a comprehensive interpretation of "learning-based, learning-used" educational philosophy. Students' learning is no longer confined to textbook, but to learn and solve work in the process of training in practical problems in life, to make teaching more reflect the personnel training standards.

\subsection{The modular vocational education curriculum deep into the knowledge points}

Micro-course is a kind of course that scientific and rational split overall teaching modules into several micro units. It is different from our modular teaching method. It makes modular thinking deep into the minutiae of course. That may be a knowledge point, or a complete operation. Although micro-course appears to be split up, but precisely because of this that makes the horizontal and vertical split holistic curriculum, and more effectively forming a comprehensive coverage of the knowledge network. Each micro-course seems independent and complete, but in reality there are a lot of association between the content. The split of knowledge is not fragmented, but to effective organized and integrated to meet the needs of learners, to meet selfconstruction purposes.

\section{THE ROLE OF MICRO-COURSES IN PRACTICAL COURSE}

\subsection{Embedding the classroom, fully mobilize the enthusiasm of students}

For some practical course, through teacher's explanation, demonstration, and then master skills by focusing on students' self-operating practice. But one lesson time is very limited, teachers explain the demonstration, and students just remember the formula in the brain over again, but it is difficult when operate by themselves. Maybe forget the sequence of steps, or forget to set parameters, even worse is completely unaware of how to do. Such a class over, students do not learn the skills for this course, and their interest and enthusiasm has also been suffer hit. So that in the classroom, students will have nothing to do, or want to learn but do not know how to start. In this case, it is particularly necessary that bring micro-course into the classroom[3]. Micro-course, it's generally only three minutes long. It highlights the difficulties of this lesson. Although it is a fragment, its structure is still intact. It is able to explain a knowledge point in detail. When students encounter difficulties in practice, it is unnecessary to ask the teacher. The micro-course can help. It is not limited to classroom teaching, also primarily based online learning or mobile learning. So that students can learn at any time. Micro-course does not replace our normal teaching, but embedded in our classroom to help students learn. 


\subsection{Leading practice, achieve people-oriented, make student initiatively}

The using of micro-course have changed the teacherled teaching professor classroom model, replaced by student-centered teaching model. Students through learning - Operation - learning - and then operate, such repeated action to implement the heavy and difficult lesson. This student-centered teaching model can avoid the students receive a lot of knowledge and content at the beginning, that makes the brain saturated. This mode achieves prominent self-discovery, self-learning and independent thinking. There is a research shows that the most effective learning time is the first 5-20 minutes, after that the learning effect and attention will be weakened. Five-minute micro-course is just suitable. So that students will consciously focus on study in five minutes. Teachers should make micro-course play its own characteristics, blend classroom content, homework and discovery into the development of micro-course, so that students can use their cell phone or mobile device in extracurricular learning.

\subsection{Seeking common ground, students learning new knowledge actively}

Achieved student-centered, serves to students' differences, diversity and the sustainable development of personalized[4].In a large classroom, teachers have to take care of all the students, so that everyone can master the basic theory, basic skills through practical action. In theoretical understanding and practical proficiency, there is often a big difference, which mentioned above is the "different."In the teaching process, we will grasp the development of all students, and cannot ignore the presence of these potential students. Micro-course has such an important feature that can be given deep explanations based on a problem, although there is only five minutes. In view of this, the micro-course is not only a guide for students in usually homework, but also can lead students to think and delve into one of the difficulties for deeper research.

\subsection{Interpreting effectively the lack of equipment and the irrational use of teachers}

Due to the equipment limitations, internships are often operated in groups. During the waiting period, the participants will have self-study, but the learning is inefficient and poor targeted. Bring micro-courses in the practice sessions, students can effectively use the waiting time. That effectively avoiding the difficulties, and ask teachers for seeking solutions. It is a good way to improve the efficiency and quality of practice.

In addition, practical lessons are usually taught by one teacher, cannot solve the problem raised by students. That requires increase the investment in teachers, which will increase school operating costs. It is a waste of resources. After bring micro-course, many problems encountered by students can be resolved without too much teachers. It is effective to use media resources, and saves manpower. Students can solve their own problems, it allows students to have a sense of accomplishment[5].

\section{WAYS TO ACHIEVE MICRO-COURSES}

\subsection{Micro-course construction mode}

\subsubsection{Own construction}

Teachers set up a team to complete the new production. The basic of construction of microcourse is teaching mode split and the design, which should be complete by teachers with many years' experience. In addition, course design involves many aspects, like knowledge itself, the role of technology, aesthetic requirements, etc., are all important elements to form good micro-course. Therefore, it is essential to form the team, in consideration of all aspects of micro-courses. That will be able to attract students formed a convenient self-learning microcourses.

\subsubsection{Adaptation of open class and quality courses}

Existing network resources are rich, and the general colleges have their own online courses or open quality courses, which can be used to re-split into micro-courses. That will conserve resources, reduce costs, and can form micro-course quickly.

\subsubsection{The introduction of high-quality micro- courses}

Many universities have begun built micro courses by themselves, many of them are already. In order to avoid duplication and waste of human resources, some quality universal micro courses can be introduced.

\subsubsection{Commission of build courses}

There are a lot of companies can help build courses, services company are generally more professional and have better results. But it must base on teachers' course design. After that the company can be entrusted and the soul remains the course itself.

\subsection{The process of making micro-course}

Micro Course produced broadly divided into three processes:

Step One: script selection and recreation.

Step two: Make PPT, set the playback speed, time, adding music, adding colophon (editor, writer, producer, music, pictures, family, etc.). 
Step three: Switch to video file (optional). In recent years, Micro-course has become a new field of teaching model with its features like flexible, shared, independent, open and efficient. It has impact of the global education community. In China, the construction of micro-courses is in its infancy, there are many places need to be studied. Aim at the status and resources of vocational education, the application research of micro-courses still have many places to discuss. It also need to be summarized and improved in practical applications.

\section{REFERENCES}

[1] The Department of education. The national medium and long-term education reform and development plan (2010- 2o20). 1667143. htm.

http://www.gov.en/jrzg/2010-07/29/content.

[2] The Ministry of education. Higher (2011) 8th: Ministry of education on the construction of national quality open curriculum implementation. 2011. 11

[3] Zhao Hui, Li Wanlong, Zheng Shanhong, Zhang LJ. Teaching reform and practice of the software project management. Software engineer, 2011, (12): 67-68.

[4] Wang Cong, Fang Guodong. Comparative study of the network teaching resources construction model of University courses. Modern educational technology, 2010, (9): 47-49.

[5] Wang Xiya, Zhou Hongchun. Practice and exploration of modern construction and application of teaching resources in colleges and universities. China audio visual, 2010, (6): 73-75. 